Article

\title{
The Commercialization of Smallholder Farming-A Case Study from the Rural Western Middle Hills of Nepal
}

\author{
Raj K. GC *D and Ralph P. Hall \\ School of Public and International Affairs, Virginia Tech, Blacksburg, VA 24061, USA; rphall@vt.edu \\ * Correspondence: rajgc@vt.edu; Tel.: +1540-257-5154
}

Received: 19 March 2020; Accepted: 27 April 2020; Published: 30 April 2020

\begin{abstract}
A vast majority of farmers in the rural middle hills of Nepal are smallholders who often use family labor and follow traditional agricultural and water management practices. This study examines a range of perspectives (from rural farmers to development experts) on the limited commercialization of rural agriculture in this region of Nepal and the potential approaches to promoting agricultural growth and commercialization among small landholders. An analysis of household surveys, key informant interviews, and focus group discussions in three wards of Kaski, Syangja, and Palpa districts of Nepal revealed that nearly one-third of farmers left their agricultural lands barren or only partly cultivated, and more than one-third were not motivated to engage in agricultural activities. This lack of motivation was found to be connected with limited or no access to irrigation water, poor production systems, a lack of access to markets, a low return on investment in agriculture, the low social status of farm-work, the incidence of crop infestations, and fear of production risks due to extreme climatic factors (such as low/high rainfall, droughts, etc.). Remittances related to outmigration were also found to be important factors limiting a farmer's involvement in agriculture, which also creates labor shortages. This research confirms that, for agricultural production to be profitable and commercial, households need to receive qualified technical support to introduce new technologies, engage in markets, access input suppliers and service providers, and adopt high-value production crops and related techniques. Households that receive an income from government jobs, private sources, and remittances reported agriculture being a laborious and difficult task. Addressing these mediating factors along with the provision of effective crop insurance and subsides for the lower-income segments of the population, has the potential to (re)engage rural households in farming activities. Such an approach could provide a way to realize the government's plans to commercialize smallholder farming.
\end{abstract}

Keywords: technical approaches; commercialization; smallholder farming; motivation; remittances; crop insurance; subsidies

\section{Introduction}

Nepal remains one of the poorest and least developed countries in the world despite more than five decades of formal development efforts. However, the country has witnessed significant progress in poverty reduction [1], living standards, food security, and infrastructure development [2]. Poverty reduced to $22 \%$ in $2015 / 16$ from $41 \%$ in 1981 [2]. Nepal's per capita income increased from $\$ 491$ in 2000 to $\$ 1034$ in 2019 [3]. However, the poverty gap in rural areas is nearly twice that in urban areas [4]. The high levels of poverty in the middle hills and mountains is due to the remoteness of communities and their lack of accessibility to markets and basic services [5]. The challenging geographic landscape represents a natural barrier to their development [1]. The 12 years of armed conflict (1994-2006), 
political instability during the transition from a monarchy to a multiparty democracy, and unstable governments during the past two decades have presented significant barriers to economic development. Rural poverty is also associated with slow growth in the agricultural sector and the rural economy [2].

Nepalese farmers have been involved in agriculture, livestock raising, and small-scale productive activities for hundreds of years. Agriculture plays a large role in Nepal's economy [6], which accounts for one-third of GDP, absorbs two-thirds of the labor force, and is the main source of livelihood for the majority of the population [1]. It is the primary occupation for the vast majority of the economically active smallholders and the poorest households. Rapid population growth and increasing urbanization in Nepal has put increasing demands on agricultural production [7]. The government, donors, and I/NGOs have spent significant resources on trying to meet this demand by increasing agricultural production. However, the capacity of Nepalese farmers to become productive commercial farmers is still limited [7]. Though the agriculture sector in Nepal has improved over the last decade, it has still not reached its potential when compared with the agriculture output of its neighboring countries $[2,8]$.

The Government of Nepal (GoN) [2] classifies the rural farm population into three groups-small commercial farmers, subsistence farmers, and landless/near landless farmers. A majority of the farm population (53\%) are landless/near landless farmers who each hold less than 0.50 ha of land. Collectively, they account for only $19 \%$ of the total available land. About $27 \%$ of the farmers practice 'subsistence farming' with land holdings of $0.5-1$ ha, representing $28 \%$ of the total land available. One fifth $(20 \%)$ of the rural families are 'small commercial farmers' with land holdings from 1 to 5 ha or above. These farmers own more than one half of the total land available [2]. The average farm size is 0.6 ha per household. Agricultural land per capita has also decreased due to the combined effect of several factors including inheritances, loss of agricultural land to urbanization, and the degradation of land [2]. Most farmers grow rice, maize, and wheat at a substance level. These crops are characterized by comparatively low yields compared to other countries in the region [1]. Samriddhi [9] shows that around three-fourths of farmers produce crops for home consumption. While it is clear that agriculture is vital to the Nepalese economy, low investment in the sector has resulted in relatively low productivity when compared with comparable regions [1].

Agricultural commercialization is a complex and long-term process. Most studies consider commercialization in terms of the volume of marketable commodities [10]. In other words, a farming family is said to be commercialized if it is selling a significant surplus of its agricultural production. The GoN [2] defines agricultural commercialization as "the transformation from subsistence production (production for own consumption), to production for sale of surplus products and services." However, the concept of commercialization is not limited to selling surplus products in markets. It must simultaneously consider both the production inputs and outputs as well as the decision-making behavior of farmers in production and marketing [10-12]. Thus, commercialized farmers need to focus on market demand when making production decisions instead of simply selling some the produce due to a production surplus.

The GoN has considered agriculture commercialization as one of the viable ways to reduce poverty and boost economic growth [9]. Agricultural development professionals have long argued that small farms, difficult terrain, limited access to farmer-friendly and low-cost agricultural technologies, a lack of all-weather road connectivity between the cities and rural areas, heavy reliance on seasonal rainfall, limited agricultural markets, and conventional farming practices remain the main challenges that hold the country in a state of poor agricultural productivity [8]. Another contributing factor is the low participation of the private sector in the agriculture sector [2]. In addition, the absence of year-round irrigation systems has limited the potential cultivation area. Climatic change and changes in the demand for agricultural products are additional factors that inhibit the growth of the sector [7]. Notwithstanding these challenges, the country is slowly moving towards market-oriented agricultural production [13].

One of the key strategies of the GoN has been to improve agricultural production and productivity and commercialize farming over the last three decades. To realize this strategy, the GoN has 
implemented several policies and programs. A 20-year (1995/96-2014/15) Agriculture Perspective Plan (APP) concluded with little progress [8]. Prior to this long-term plan, the GoN had given priority to agricultural development through the country's first 5-year development plan (1975-80) [9]. In 2016, the GoN initiated the Prime Minister Agriculture Modernization Project to enhance agricultural productivity and achieve commercialization of agriculture (with the allocation of Rs. 5.75 billion, USD \$51 million). The GoN has also recently launched the Agricultural Development Strategy (2015-35) with support from the Agricultural Development Bank (ADB), as well as the 2018 "Roadmap to Prosperity". These policies aim to promote the commercialization of agriculture and enhance the Nepalese rural economy [14].

Development experts argue that the execution of these policies and programs has remained weak, as resources and institutional capacity needed for their delivery are limited. The GoN has also acknowledged that the leading stakeholders, particularly farmers, cooperatives, and private sectors, were not proactively involved in the development and implementation of existing policies and programs [2].

This paper seeks to understand the institutional and technical barriers to expanding smallholder farming in the western rural middle hills of Nepal. The rural middle hills present an opportunity to study commercialization of smallholder farming due to the long engagement of farmers in cereal crops, high-value crops (such as vegetable crops that provide a higher return per unit of land and have a higher market demand than staple crops such as cereal crops), and livestock production. These farmers also have limited experience in selling these commodities in formal markets. This research aims to inform policy makers on appropriate policies that could advance the commercialization of smallholder farming in the region. The paper is timely given the GoN's efforts to develop hundreds of new polices in all sectors of the economy following the new federal constitution established in 2015.

The paper is structured as follows. Section 2 presents the methodological approach and describes the study area and the data collection and analysis techniques used. The findings are presented and discussed in Sections 3 and 4. Section 3 is organized into subsections on the constraints to commercialization of agriculture, and the impact of remittances on agriculture and the role of women in agricultural commercialization. Section 4 then explores approaches to advance the commercialization of agriculture in the middle hills of Nepal. The relationships between the socio-economic characteristics of households and crop incomes are presented in Section 5. Section 6 presents a series of recommendations and Section 7 concludes the paper.

\section{Methodology}

\subsection{Study Area}

Nepal is a mountainous country located in southeast Asia, bordered by India and China. It is officially divided into three ecological zones-the Terai, the Hills, and the Mountains. It ranges from fertile plains in the south (57 m above sea level) to mountains in the north (up to $8886 \mathrm{~m}$ above sea level) [15]. The 2015 federal constitution of Nepal formed one federal, seven state, and 753 local governments (LG). These LGs were divided into 6743 wards [16]. They represent the lowest administrative unit of the government.

The research site is located in three wards (Annapurna-6, Waling-5, and Bagnaskali-1) of Kaski, Syangja, and Palpa districts in the western middle hills region of Nepal (Figure 1). Kaski and Syangja districts are located in Province- 4 and Palpa in Province- 5 as depicted in Figure 1 . More than 1500 households live in these three study wards. Agriculture is one of the major occupations and sources of livelihood for a majority of the population in these areas. Typically, families grow cereal crops-rice, maize, wheat, and millet on terraced fields. In 2018, per capita income in this region was around USD $\$ 850$ [17]. The major sources of income for these families include remittances (income from men working outside the country) $(41 \%)$, jobs (22\%), agriculture (excluding consumption) $(15 \%)$, business $(10 \%)$, pensions (11\%), and government allowances (1\%) [17]. Over three-quarters of the households kept animals with approximately six animals per family on average [17]. 


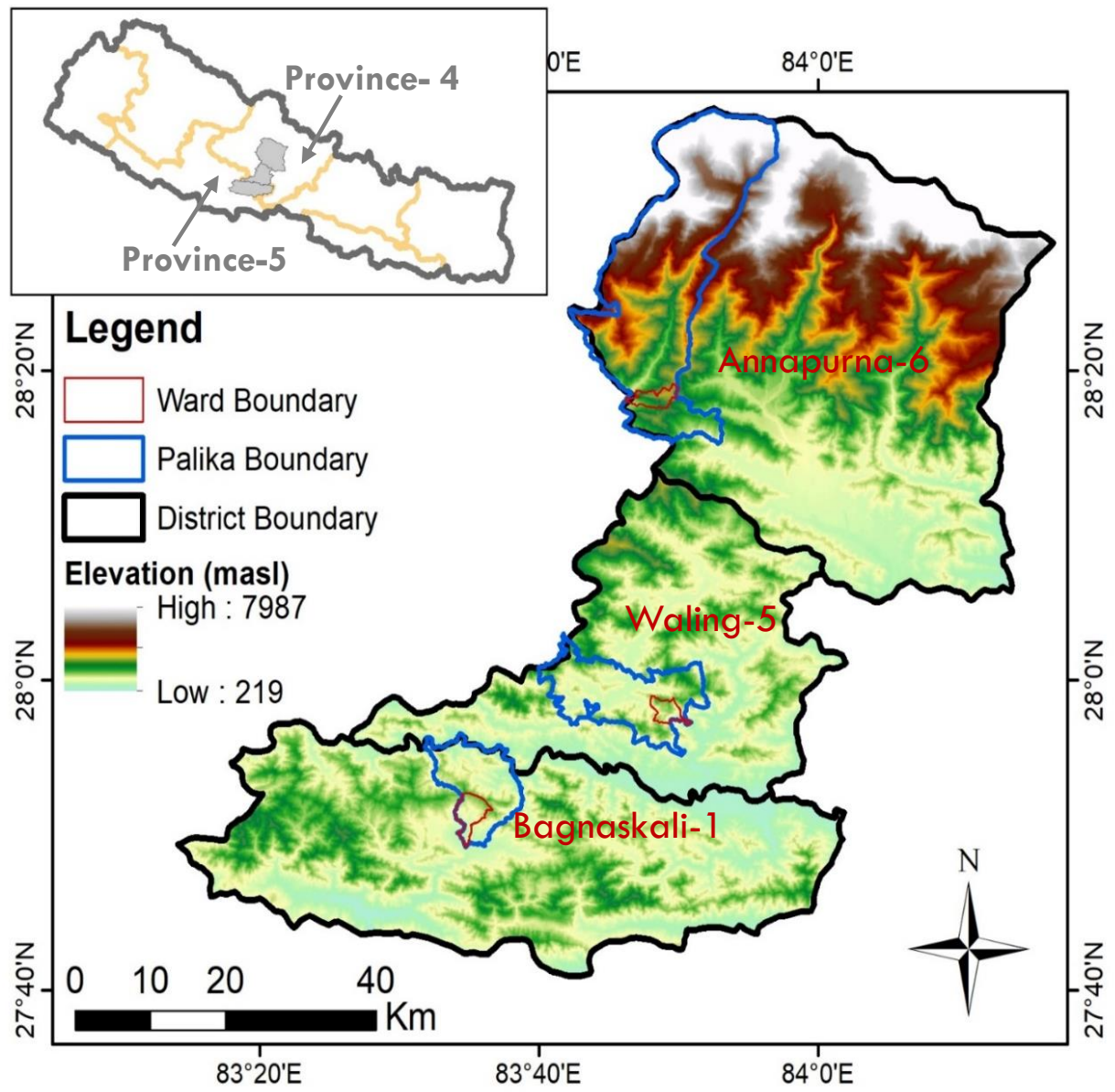

Figure 1. Study area.

Agriculture and forestry are the dominant forms of land use in the region. Khet and Bari lands are the two common types of cultivated land. The Khet land often consists of leveled terraces that are primarily used for cereal crop production, and are located away from households. Whereas, Bari land is a small land area close to the homestead. The cultivated Khet lands depend mostly on monsoon rains from June to September with more than $75 \%$ of the annual rainfall occurring during this period $[14,17]$. There are three distinct seasons in the middle hills: rainy, winter, and hot summer [18]. The elevation of the three districts included in this study range from 219 to $7987 \mathrm{~m}$ as shown in Figure 1. Landholdings are small and fragmented, which is a common phenomenon across the middle hills and mountainous regions [19]. All three of the studied wards were located about $10 \mathrm{~km}$ from the district headquarters. Each ward was also located around $3 \mathrm{~km}$ from the nearest highway.

\subsection{Data Collection and Analysis}

The research for this paper was conducted between October 2017 and July 2018. First, villages that met a preliminary set of criteria were shortlisted, primarily related to their use of rural water systems based on (1) data from an International Non-Governmental Organization and (2) their geographic location in the middle hills of Nepal. Second, the lead researcher visited the three shortlisted sites and assessed their access to agricultural markets; the water systems being used; experience with improved agricultural practices; involvement with cereal, high-value crops (HVC), and livestock production; and willingness to participate in the study.

The methodology consisted of household surveys, focus group discussions (FGDs), key informant interviews, and field observations. A total of 202 household surveys were conducted to gather data on the use of water for irrigation, the farmers' agricultural practices, their engagement and motivation 
in agriculture, and factors constraining production. Ten FGDs with farmers were undertaken to gather information on their experiences and beliefs relating to agricultural issues. The lead researcher provided different topics for discussion and the participants were given sufficient time to discuss each topic. The participants were then given time to present the results of their discussion. The farmers included in the FGDs were members of agricultural production groups and/or the community's water committee. The FGDs were designed to elaborate on the results obtained from the household survey.

Interviews with 50 key informants (KI) - 10 in each of the studied wards-were also conducted. The interviewees consisted of local government officials, elected representatives, local leaders, officials from agricultural cooperatives, agriculturists, and agriculture input suppliers (agro-vets). The key informants were identified through local NGOs, municipalities, and conversations with lead farmers (farmers who have received extensive trainings and grow crops at a commercial scale). Key informants' perspectives are critical given their local agricultural knowledge.

The methodology consisted of a mixed-method approach that involved data collection and analysis using both quantitative (household survey) and qualitative methods (key informant interviews and FGDs). A 'hand coding' technique [20] was used to organize the qualitative data gathered from the key informant interviews and FGDs. The research was designed in a format that the household survey complemented the FGDs and KI data. Such integration of quantitative and qualitative methods [21] offered an effective way to understand the barriers to the commercialization of smallholder farming and how they might be overcome. The use of these methods permitted the triangulation of data around critical or emergent themes [22]. The responses received from the key informant interviews were classified into different themes through grouping and regrouping. The themes were then linked, as appropriate, to consolidate the explanations [23] and connect them with the challenges and opportunities facing efforts to commercialize smallholder agriculture.

\section{Findings and Discussion}

\subsection{Constraints to Commercialization of Smallholders-Informant Perspectives}

Nearly all the surveyed households were engaged in some kind of subsistence activity relating to growing vegetables, oilseeds, pulses, cereal crops, and fruits, rising livestock and poultry, and horticulture. However, more than three-quarters of the households $(83 \%)$ were engaged with the cultivation of major cereal crops-rice, maize, and/or wheat. Almost all of the households $(90 \%)$ grew vegetables, and more than half of the household (58\%) sold them to vegetable collection centers, with the remainder either selling them to neighbors, hotels, or wholesalers who collect from their residence. Less than $4 \%$ of the households sold through all four of these options. Cattle, buffalo, and goats were raised by over two-thirds (70\%) of households. A similar percentage of households $(69 \%)$ kept chickens. Families were mostly subsistence producers living off marginal land of about 0.5 ha. Most households lacked access to year-round irrigation. These data reveal that agriculture is still a basic source of income for these communities. The following statement by a farmer highlights why most rural households rely on agriculture.

"My grandfather and father were farmers. I started helping my father on the farm when I was just 15 years old. This is how I learned farming from an early age. I think my core skill is farming. I do not have the skills to work for an office or sit behind a computer for a high paid job. I enjoy working on my farm" (Interview, farmer, December 2017).

More than one-third of the Khet lands were found to remain uncultivated throughout the year. Nearly half of the households reported that they lacked labor during the land preparation and harvesting time. Another one-third of families were not growing cereal crops in the dry season due to a lack of irrigation facilities. In most of the areas studied, only small amounts of wheat and pulses were grown during the winter dry months. Since the cultivated lands mostly depend on monsoon rains, the informant agricultural experts believed that regulated and controlled year-round irrigation would enable farmers to grow crops during three seasons in a year. While a vast majority of the households 
surveyed produce cereal crops for self-consumption, a little over one-third sold their surplus. Less than half of the households needed to buy rice, wheat, and maize for a majority of the year. These findings correspond to evidence that there has been a significant reduction in the production of cereal crops. For example, while the Kathmandu Post [24] reported that Nepal imported Rs. 51 billion (USD 451 million) of food grains, Rs. 28 billion (USD 248 million) of vegetables, and Rs. 37 billion (USD 327 million) of cooking oil in 2018, local agricultural experts argued that the current production of these crops is considerably lower than what is possible.

There was general agreement among the key informants that livestock raising and farming of cereal crops (rice, wheat, and maize) have been drastically reduced in the last decade. The household interviews revealed that livestock raising has declined by $15-20 \%$ during this timeframe. The decline of raising livestock was found to be associated with a shortage of labor due to the outmigration of youths and a lack of pasture land, fodder, and open space for livestock (FGDs, production groups, November 2017). Additional barriers to raising livestock were poor nutrition and disease among animals [25]. In addition, more than half of the farmers interviewed complained that laborers were not willing to work on their farm due to the small financial incentives.

The informants reported there was minimal to no support from the government and NGOs for cereal and livestock production. However, the government and NGOs were providing production-related support for high value crops (HVC) for more than half of the households. There was only a small percentage of households $(12 \%)$ who received technical support relating to livestock-e.g., how to use improved cowsheds, available veterinary services, etc. Most farmers reported they lacked access to a full range of inputs and technologies. In addition, interviews with some farmers revealed the lack of respect for farming as a disincentive to farm. "Farming profession is not well respected, rather perceived as a low-rank profession. This is a pity. All need to understand that farmers not only produce for themselves, they also produce for others, so they are shared property" (Interview, farmer, November 2017).

Most of the households utilized their Bari lands for vegetable and livestock production. Bari lands were mostly irrigated with water systems designed for domestic uses, which constrains the growing of crops to a small portion (6.2\%) of their Bari land. This result indicates that a large proportion of the Bari land could be brought into cultivation during the dry season if they had a reliable source of irrigation water. Less than one-fourth of the households had access to water to irrigate a larger area of Bari land. However, nearly one-half of these households limit crop production to small plots because they fear crop failures or low crop yields due to infestations and extreme weather. Farmers cultivating in marginal lands also increase the risk of land degradation and fertility loss due to mono-cropping (Interview, NGO, June 2018). These factors reinforce the lack of motivation among one-third of the farmers to produce crops on Khat and Bari lands.

In summary, the common reasons for reduced levels of crop production are the lack of a viable workforce, alternative off-farm sources of income, a limited return on crop-related investments, a shortage of inputs and fertilizers, the use of inefficient production techniques, and production risks associated with technology, irrigation, and marketing (FGD, January 2018). These factors collectively explain the constraints faced by smallholders when considering the commercialization of farming. Interestingly, over one-third of the farmers did report that they foresee a commercial and market-oriented future.

\subsection{The Impacts of Remittances on Agriculture and the Role of Women in Commercialization}

Agrilinks [26] reported that more than two million young Nepalese, especially men, work outside of the country in low-skilled jobs. At least one youth male from more than one half of the households surveyed (54\%) had out-migrated, mainly to the middle east for (mostly unskilled) employment. This male outmigration is associated with the critical shortage of farm labor. Remittances related to outmigration provide a significant cash inflow to households. It is estimated that migrants send $\$ 6.1$ billion per year (54 million USD) (31\% of GDP in 2014/15) home via remittances [2]. Low productivity, 
small farm size, and the low social status of farm-work are primary factors that have discouraged youths from getting involved with farming [24]. Labor migration has had a significant effect on land management and production in the middle hills of Nepal [27]. Remittances have resulted in improved food security and a decrease in dependency on farming [27,28]. More than two-fifth (43\%) of the households receiving a remittance reported that they spent most of it on loan repayments and consumption including food, education, health care, and upgrading their homes or building new homes. In reality, only a small amount of their remittance income was spent on agriculture. Samriddhi [9] has argued that these remittance incomes could be more productive if they were directed towards high-value agriculture.

Several migrant returnees interviewed for this study became engaged in commercial farming and livestock production. Each individual was considered to be a model farmer in their community, earning more than USD $\$ 12,000$ per year. One of the returnees commented: "It was so hard to work in the hot of the Middle-East as an unskilled worker. I learned how hard it was to earn money. This made me realize that I would do something in my own country that I know and can do. After two years, I returned to my village and took some loans from a cooperative and relatives for goat farming. It has become profitable. My family is happy and I am happy too" (Interview, youth farmer, June 2018).

Women were also found to play a crucial role in agricultural production and food security. Nepal has a relatively strong female labor force [1]. Despite the fact that the involvement of women in agricultural activities is very intensive [29], their contribution to agriculture has not been fully recognized. These responsibilities render women vulnerable to declining water supplies, climate variability, natural disasters, pest outbreaks, changing precipitation patterns, and other impacts from climate change [7]. Project planners often tend to limit women's involvement in the entire process of planning, programming, and implementation of development activities (Interview, lead women farmer, July 2018). As a result, such projects have either failed to meet their objectives or have made little impact on agricultural development [7]. The key informants favored women's participation because they already play a major role in producing, harvesting, and marketing many types of crops. The following statement from a key informant indicates how the role of women has changed in the community. "The management of major crop production has traditionally been the male domain. Since most male youths have migrated to foreign countries for income, women are increasingly involved in crop and livestock production. Most people trust women now a days. This was not the case 10 years before. This shift is gradually breaking strict traditional divisions between the roles of men and women" (Interview, social activist, January 2018).

The limited presence of youths in the villages has negatively impacted socio-economic activities. For example, the work burden of women and elderly people related to household activities has increased. Similar findings were reported by Jaquet et al. [27]. Youth outmigration has required women to engage in agricultural and water groups, local water system planning and construction (e.g., the selection of water sources, locating taps and tanks, etc.), and trainings to increase their knowledge and capacity relating to agriculture and water management. These activities have led to shifting gender roles with women becoming entrepreneurial and engaged in extra-household activities. However, the key informant interviews and FGDs highlighted that women required training in value-added production, post-harvest handling, and agro-processing techniques. In addition, rural institutions need to be developed that provide agricultural services to women and opportunities to engage in decision making. For example, linking women's groups to credit sources in order to overcome the financial constraints that many female-headed households face would help overcome a significant entry barrier to small-scale agriculture [7].

\section{Approaches to Commercialization}

By carefully reviewing the perspectives of key informants on the technical approaches to promoting the commercialization of agriculture in the western middle hills of Nepal, six key themes were identified. These themes include production training and capacity building, access to irrigation systems, access to 
agricultural inputs, services and markets, the use of improved agricultural technologies and practices, risk reduction measures and approaches, and HVC and livestock intensive agriculture. Each theme is discussed below.

\subsection{Production Training and Capacity Building}

Interviews with the key informants revealed the need for comprehensive training on crop planning, improved agricultural practices, pest management, soil health improvements, crop harvesting and marketing, and the use of crop calendars by producers. Exposure visits to successful farms was also considered to be an important tool for capacity development (Interview, local NGO, June 2018). Such visits enable farmers to observe successful farms and interact with their owners. Some local elected ward representatives advised agricultural experts to develop need-based trainings that identify the users' specific knowledge and skills and address agro-climatic requirements. Farming families generally have limited skills in systematic record-keeping of their production and sales. As a result, many farmers did not know if they were making a profit or loss.

Farmers were found to need additional training on commercial planning and record-keeping, including income and expenditure records and unit cost calculations [7]. These activities are expected to empower farmers with the required technical knowledge and help them organize input supplies, improve the application and use of available technologies and practices, and enhance their access to markets for their products. In addition, the key informants recommended an increase in the number of women, marginalized, and disadvantaged groups included in new farmer groups and in the selection of farmer training programs. Farmers are organized into production groups, but in an ad- hoc way. As one local elected representative commented, "I urge the supporting NGOs to create local expertise by providing a complete basic training package to the groups and long-term ToT [Training of Trainers] trainings to selected farmers who could train other farmers as a service provider. Such a mechanism can promote activities at the local level even after the withdrawal of project support" (Interview, local elected representative, June 2018).

A sustainable mechanism to train farmers would be to select lead farmers to receive ToT training so that they can pass on information and skills to other farmers (Interview, NGO, May 2018). Such a locally transferable capacity development model can create a long-term approach that is collectively owned and managed by local people. It was recommended that programs focus on working with small farmers to prioritize and implement activities relating to crop diversification, commercialization, and productivity (Interview, INGO, June 2018).

\subsection{Access to Irrigation on the Farms}

The topography of the middle hills of Nepal makes the development of irrigation systems costly and technically challenging [30]. In many cases, surface water sources are located below the settlements and require high-cost pumping technologies to lift water to communities. Besides the cost of these pumps, most installed systems suffer from poor operation and maintenance and have proved to be unsustainable. Studies in the region consistently find that it is unfeasible to access groundwater from a technical and financial perspective. Over the past decade, some efforts have been made, mainly by non-governmental and private sector organizations, to promote non-conventional irrigation technologies (NIT) such as drip irrigation and sprinklers for vegetable crops, but the pace of adoption by farmers has been slow (Interview, local dealer, December 2017). One farmer remarked that "Most farmers depend on rainfall for the crops. Some farmers want to grow crops that do not need irrigation or just a small rainfall would be sufficient. Three to four monsoon months matters much to farmers like me" (Interview, key informant, November 2017).

A vast majority $(89 \%)$ of the informants claim that the development of irrigation systems, will not only increase the cropping intensity of winter crops (i.e., wheat), but will also enable farmers to grow maize and other crops during the dry season. The yield levels of existing crops could also substantially increase. Agricultural experts anticipate that year-round irrigation systems would significantly increase 
farmer's motivation to engage in agriculture, especially those farmers who scaled down farming due to a fear of droughts or lack of irrigation water. Reliable irrigation during the dry months has tremendous potential to enable new income generating activities for smallholder farmers (Interview, agriculture expert, January 2018).

\subsection{Access to Agricultural Inputs, Services, and Markets}

The lack of access to appropriate direct farm inputs is seen as a significant constraint to enhancing the productivity of rural farmers. More than two-thirds (69\%) of informants highlighted the need to provide improved access to agriculture inputs and technologies to smallholder households through a market-driven/private sector supply chain. This study found that most of the input suppliers were located in the district headquarters. Due to the rugged terrain and geographical constraints, a place to buy inputs is often not within comfortable walking distance from the communities. Moreover, most input suppliers have limited knowledge of their products and do not stock the proper inputs such as seed varieties, fertilizer, and pest control technologies. Most input providers were selling improved seeds, fertilizer, and equipment without any systematic training and lacked knowledge of plant protection methods and pesticide classification and uses (Interview, agriculture expert, January 2018). Key informant experts recommended that input providers work with stockiest, exporters, and producer organizations to provide small-scale farmers with access to affordable fertilizers, chemicals, and quality seeds. More than two-thirds of the informants highlighted the need for a support program that would develop products and service packages tailored to the needs of identified markets and engage in demand creation activities. Such programs can develop linkages with a network of farmers groups and NGOs interested in demonstrating and disseminating information on the benefits of intensifying production using improved inputs and practices. One local agriculture supplier argued that "To create sustainable supply, the government and project should invest in developing the capacity of manufacturers, assemblers, agro-vets, leaders, farmers, installers in the supply chain, and in ensuring that the supply chain generates benefits in terms of increased income from the production and/or sale of the products and services. To generate sustainable demand, the activities will need to launch a rural mass marketing campaign" (Interview, local agriculture product supplier, December 2017).

Most of the study villages were connected to a highway by rural gravel roads. Nearly half of the households were linked to a vegetable collection center and dairy that sold dairy products. There were no formal centers or markets for cereal crops and livestock. The key informants revealed the need for a profitable and expensive private sector supply chain (made up of manufacturers, distributors, agri-input dealers, and produce marketers) to produce, distribute, and sell affordable service packages and to profitably sell farm produce. As a political leader commented, "In our area, market access is weak for all kinds of production. To addresses this problem, a key intervention is the establishment of locally managed market facilities that link to traders and farmers. It is important to ensure that farmers gain access to information on market demand, price, and production. Development of local markets may overcome the uncertainty of sales and maximize income and profits from crops and livestock" (Interview, political leader, January 2018).

In summary, more accessible and competitive input and output markets would enable rural people to find their own way to agricultural production and provide more choices and opportunities. It was also recommended that the GoN develop livestock markets, well-equipped collection centers, and storage facilities in partnership with the private sector to improve the efficiency of the agricultural market (Interview, local NGO, July 2018).

\subsection{Use of Improved Agricultural Technologies and Practices}

Traditional farming is widely practiced in the research area, which consists of indigenous production practices, conventional tools, and weather dependent seasonal crops. Local experts suggest that farmers may gain high yields if they use improved production practices and technologies. Some of these improved practices and technologies include crop selection and planning, nursery 
preparation, crop production and management, production technologies, post-harvest techniques, use of micro-irrigation technologies, and production and marketing trainings and services. These technologies and services, when combined together, were found to enable households to increase their income by NRP 44,500 (USD \$445) per year from small-scale productive activities (excluding incomes from cereal crops), which is a significant income for a rural family [17]. In order for farmers to take advantage of improved technologies, the government should subsidize the needed technologies for lower-income segments of the population. Put simply, subsistence farmers need subsidies [9]. As a female farmer commented, "When I used a plastic house and hybrid seed, I become able to grow off-season vegetables. I also used drip irrigation to irrigate the vegetables. My vegetable farm has become successful. I earn more than NRP 1,000,000 [USD \$9000] per year. My husband has returned home last year who was working overseas. The increased income is the reason why he returned home" (Interview, female farmer, December 2017).

Local NGOs working in the region argued that effective crop and livestock insurance is vital to motivate and engage rural farmers in agricultural production. Farmers face a series of challenges in developing and promoting crop and livestock insurance products and services that are suited for smallholder farmers [2]. Many of the farmers interviewed also lacked knowledge and awareness of insurance. Some of the cooperative and microfinance NGOs offer crop and livestock insurance services. However, these services are costly and narrow and are not receptive to the needs of farmers (Interview, Local NGO, June 2018). Many of the insurers have a limited service network in rural areas. Therefore, insurance services need to be expanded and brought in line with international standards [2].

The NGOs and experts interviewed also highlighted the need for time series data on crop production and yields. Such data can help determine the appropriate crop choice for different micro climatic zones. These data can also inform the development of appropriate crop insurance products and services. In addition, necessary incentives such as promotion grants, awards, and revolving funds could play a key role in increasing the current level of agricultural production (Interview, political leader, June 2018).

\subsection{Risk Reduction Measures}

Most of the Nepalese hills are characterized by fragility, marginality, and inaccessibility, making them vulnerable to the impacts of landslides, flooding, and climate change [5,15]. Recent climate projections suggest that Nepal's agriculture and ecosystems will face many challenges over the coming decades due to climate-related variability such as water scarcity, declining yields, and outbreaks of pests and diseases [31,32]. A majority of local informants (57\%) reported that they have experienced changes in rainfall patterns (such as less frequent, but more intense rainfall events and unpredictable and erratic rainfall patterns), increased frequency and intensity of floods, and longer dry spells and drought events. Several informant farmers reported a fear of production risks due to these extreme climatic factors. "In 2015, we had a big landslide that swept away several homes and destroyed crops. Hailstorms destroy crops every year. We never know when the corps will be destroyed. There is no guarantee that we will be able to harvest the crops and hard work evaporates instantly. This is a big frustration for a producer like me and many others hesitate to extend their agriculture because of these risks" (Interview, lead farmer, January 2018).

In addition, there is a sharply growing trend that farmers, especially the vegetable producers, depend on pesticides to grow their crops [33]. More than one-third of the farmers interviewed reported that the incidence of pesticide resistant insects is becoming more intense and alarming. Further, some of the experts interviewed linked this problem to the haphazard use of pesticides and the changing climate that create a favorable environment for these pest and insects.

Poor and marginalized households are more vulnerable than those with larger plots of land and a high household income [2]. Further, marginalized communities have fewer options to deal with environmental shocks and stresses. Therefore, opportunities to integrate and link adaptation interventions and mechanisms to the development planning processes at different levels are critically 
important. To deal with the impacts of disasters/risks, experts proposed adaptation activities that focus on resistant crop varieties, improved governance, and capacity building at the local level. Government and NGOs should train and encourage farmers to promote crops that are resistant to droughts and floods (Interview, leader farmer, December 2017). The experts interviewed suggested the promotion of adaptation strategies for the most vulnerable communities that center around improving access to agricultural technologies and services.

\subsection{High-Value Crops (HVC) and Livestock-An Opportunity for Smallholder Farmers}

High-value crops can provide higher income per unit of available water and land (Interview, agriculture expert, December 2017). HVC can generally result in three or more times the net income obtained from traditional cereal crops (Interview, NGO, January 2018). There was a common view among the key informants that the off-season production of HVCs generates a higher income than can be obtained from the main growing season. "I grow vegetables in a 500 sq. plot and keep six livestock (one cow, three goats, and two oxen). We have also some chickens. I sell surplus vegetables in the local market. I also sell some milk, goats, and chickens. They have been closely aligned with my family as an important source of income and livelihood. I want to produce vegetables in larger scale and keep more livestock, but I lack money and labor" (Interview, farmer, June 2018). HVC was also considered to be compatible with low technology greenhouses and locally appropriate and efficient micro-irrigation techniques (MIT) (Interview, NGO, December 2017). According to some of the experts interviewed, these greenhouses enabled off-season vegetable production by creating heat in the winter. Those farmers using greenhouses to grow HVC, also described them as an effective way to protect against monsoon rain and hailstorms. Further, the combination of greenhouses with MIT technologies were found to be effective for HVC production.

According to the agriculture experts interviewed, variations in altitude are advantageous in growing high-value crops, not only for the main season crops but also for off-season production. When selecting a particular HVC for a particular site, a number of factors need to be considered: the location of the site; accessibility to markets; the local farmers' knowledge and experience; etc. (FGD, Syangja, January 2018). The FGDs also revealed that HVC are appropriate for smallholder and marginalized farmers, as these crops require less capital investment and provide a quick return to meet their more immediate needs. Reliable access to local markets with a cold storage facility would help attract farmers to HVC production.

The key informant interviews highlighted the potential for livestock, especially for goats and milk in the region. It difficult to sustain rural livelihoods without keeping livestock (Interview, community leader, December 2017). More than one-fifth of the informants favored livestock production due to the higher financial return and high nutritional value. However, access to health services for livestock, a lack of proper breeding, poor animal husbandry practices, and rampant animal disease remain major challenges for farmers. Nepal's poor market access and road conditions create a challenge to deliver livestock feed to rural areas, which means farmers have to rely on local fodder products to feed their animals. Such isolation can put livestock holders at risk in rural areas [34]. Households need improved livestock sheds, available nutritious fodder, forage management knowledge, veterinary services, and improved livestock keeping and management practices to improve livestock productivity.

Utilizing Commercial Pocket Approach (CPC): A Model for the Commercialization of HVCs

With limited private sector investment and overstretched government extension services, Nepalese farmers have suffered from low productivity and poor markets. As discussed in previous sections, agricultural production is primarily for subsistence and only a small portion of the crops grown are sold despite a strong demand. To overcome these challenges, International Development Enterprises (iDE Nepal), an International NGO, along with partner NGOs have promoted the commercial pocket approach (CPC) [35]. The CPC is a defined pocket area that is established to mobilize smallholder farmers to produce a marketable volume of HVC, sufficient to justify the creation 
of a community-managed collection center [36]. In addition, the private sector is encouraged to establish local extension agents (known as community business facilitators) to market essential inputs, equipment, and services through door-to-door services in coordination with production groups. The CPC approach envisions that a production group, i.e., farmers in the pocket area, is formed in every village within the collection center service area. The farmer groups elect their members to form a marketing and planning committee (MPC). The MPC then establishes a collection center to accumulate farmer produce for traders/byers. An MPC serves multiple functions such as organizing collection centers, mobilizing necessary agricultural inputs and extension services, developing linkages with the government and private sector to make their agricultural services available to farmers (e.g., trainings, access to credit, etc.), and advocating for needed rural policies and infrastructure such as water supply, agricultural roads, and collection centers, among others. The MPCs are expected to register and function as cooperatives.

When the volume of crops at a collection center increases, support services such as technical assistance, input supplies, marketing services, and education and leadership trainings are expanded for the producers. As a result of this growth, communities are likely to support the establishment of more rural collection centers and the marketing of agricultural products may extend from local markets to regional markets and beyond. One key informant described the CPC model as follows: "The key principle of the CPC approach is to focus smallholder vegetable production in a defined area that will create a demand for a range of input and marketing support services with an optional goal of engaging farmers in improved production activities. It enables the farmers to learn the principles of business enterprise such as records keeping, preparing a business plan, and production and marketing planning. Production groups also learn the principles of collective marketing and experience the institutional development of the cooperative/collection center they are associated with. The role of external agencies (i.e., NGOs) will be reduced when production groups within the commercial pocket become technically competent" (Interview, INGO, June 2018).

\section{The Relationships Between the Socio-Economic Characteristics of Households and Agricultural Incomes}

Table 1 shows how different household-level socio-economic factors and production practices are associated with the income from agricultural production (including livestock). Households that received an income from a government job or remittances report agriculture being a laborious task. As a result, they obtain a low level of income from agriculture. One-third of households reported being less motivated to pursue agriculture due to the required hard work. Interestingly, households with an income from government jobs and other secured sources of income were less engaged in farming and viewed agriculture as a difficult profession.

While a majority of the households were engaged in improved crop production due to an external project, less than one-third of the households abandoned these practices after the project support had ended. More than half of the surveyed households used improved seeds, two-fifths sold crops in a formal market, and nearly one-quarter of the households applied Integrated Pest Management (IMP) practices or used low-technology greenhouses. More than one-third of the households used improved technologies and practices. Some of these households developed additional sources of water to irrigate their plots. Table 1 shows that households making a high income from agriculture used improved seeds (high yielding varieties), sold crops in local formal markets, and used non-conventional irrigation technologies (drip, sprinklers, manual water sprayers, etc.), surface or piped irrigation, and improved livestock production technologies.

While the households using improved technologies and practices sell crops in formal markets (e.g., collection centers, hat-bazar, etc.), the households growing traditional crops often sell to nearby hotels or informal markets. The use of agricultural technology and easy access to markets were considered as critical factors in commercial production. In addition, access to production, marketing, and post-harvest training enabled farmers to improve agricultural production and income. Households 
experiencing higher economic benefits from agriculture were found to engage in more production activities when compared with farmers that did not experience such financial gains.

Interestingly, more than one half (51\%) of the households with women (aged between 15-50 years old) who were actively engaged in production activities were earning a high level of agricultural income (Table 1). These households were largely engaged in small-scale production activities such as HVC and livestock production and marketing and selling of dairy products. These production activities accounted for more than three-quarters of their total agricultural income. More than one half $(55 \%)$ of the women interviewed also reported that outmigration of their husbands increased their role both in the household and with regards to small-scale agricultural activities. Notably, a majority of the women experiencing this situation also received a remittance and earned a high level of agricultural income. Women's increasing involvement in agricultural production groups and engagement in trainings were also found to increase their knowledge of, and capacity to engage in, small-scale agricultural production.

Table 1. Characteristics of production households.

\begin{tabular}{|c|c|c|c|}
\hline \multirow[b]{2}{*}{ Households (HHs) Characteristics } & \multicolumn{3}{|c|}{ Agricultural Incomes (Cereal Crops, HVCs, and Livestock) } \\
\hline & $\begin{array}{l}\text { \% of HHs with High } \\
\text { Agricultural Incomes } \\
\quad \text { (>\$801/year) }\end{array}$ & $\begin{array}{l}\text { \% of HHs with Medium } \\
\text { Agricultural Incomes } \\
(\$ 401-800 / \text { year })\end{array}$ & $\begin{array}{l}\text { \% of HHs with Low } \\
\text { Agricultural Incomes } \\
\quad(<\$ 400 / \text { Year })\end{array}$ \\
\hline $\begin{array}{l}\text { Women (aged between } 15-50 \text { years old) actively } \\
\text { engaged in a HH's agricultural production activities } \\
\qquad(n=99)\end{array}$ & 51 & 20 & 29 \\
\hline HH has reliable access to irrigation $(n=115)$ & 50 & 26 & 24 \\
\hline Agriculture is the main $\mathrm{HH}$ occupation $(n=105)$ & 47 & 30 & 23 \\
\hline $\begin{array}{c}\mathrm{HH} \text { receives production support from local or/and } \\
\text { external agencies }(n=94)\end{array}$ & 45 & 30 & 25 \\
\hline HH sells produce in a formal market $(n=85)$ & 42 & 26 & 32 \\
\hline HH uses improved production technologies $(n=109)$ & 41 & 34 & 25 \\
\hline $\begin{array}{l}\text { HH member has received production/skills training } \\
\qquad(n=121)\end{array}$ & 41 & 35 & 24 \\
\hline HH uses improved seeds $(n=117)$ & 40 & 30 & 30 \\
\hline $\begin{array}{l}\text { Small business provides an alternative off-farm } \\
\text { sources of income }(n=37)\end{array}$ & 32 & 24 & 44 \\
\hline Main income source-government job $(n=19)$ & 29 & 25 & 46 \\
\hline $\begin{array}{l}\text { Highly educated HHs (university education } \\
\text { or above) }(n=49)\end{array}$ & 25 & 30 & 45 \\
\hline Main income source-wage $(n=34)$ & 23 & 31 & 46 \\
\hline HHs earning remittances $(n=109)$ & 23 & 37 & 40 \\
\hline Low productive lands $(n=71)$ & 17 & 35 & 48 \\
\hline
\end{tabular}

\section{Recommendations}

Based on the findings of this research, the following recommendations are proposed for the GoN and organizations working with rural farmers in the middle hills of Nepal to commercialize smallholder farming.

- Overcoming the constraints to commercialization: to increase a household's agricultural production skills and ability, the government and funding agencies should address the constraints to commercialization revealed in this study. For example, farmers holding less than 0.5 ha of land need direct support in the form of subsidies, tools and techniques, and capacity development. In contrast, farmers who are already undertaking commercial activities could benefit from business development training and other knowledge related to important areas such as health and environmental protection (e.g., the appropriate use of insecticides and pesticides).

- Providing insurance services and loans: users were found to fear risks such as production failures, pest infestations, low crop yields, limited availability of livestock fodder and space for grazing, and uncertainty of sales after production. These factors have discouraged smallholder farmers from undertaking commercial agricultural activities [6]. Therefore, any support strategy should address these challenges, including the provision of effective crop and livestock insurance services and agricultural loans to small commercial farmers. 
- Enhancing the role of the private sector: in addition to the existing role of the private sector in providing agriculture inputs, the government should work to increase the role of the private sector in providing technical knowledge, business skills, and agro-enterprise development. Policies should recognize the role of private sectors as service providers. The sustained involvement of the private sector is critical to making agricultural services more effective.

- Addressing outmigration: labor shortages due to male outmigration and a lack of youth interest in agriculture have become a serious concern in the agriculture sector. It is important to engage returned youth (from outside of the country) in agricultural production by making agriculture more profitable and attractive. This concern should be addressed by government policies and programs.

- Aligning agricultural programs with local micro-climate and farmer's needs: the lack of agricultural programs that align with local micro-climates and farmer's needs is a factor constraining the advancement of the agriculture sector. Research is needed to understand the appropriate crops, production, and extension strategy for different micro-climatic zones, even within the middle hill regions.

- Strengthening agricultural policies, projects, and programs: the weak implementation of agricultural policies and short-term focus of agricultural policies and programs present barriers to agricultural development. Therefore, government and international development agencies should focus on implementing appropriate policies and long-term and sustainable agricultural development projects and programs. These efforts should also focus on enhancing effective governance from the federal to local level.

- Supporting and protecting local production: While agricultural production is highly commercialized in Nepal's neighboring countries (i.e., India and China), the subsistence level of agricultural production in Nepal increases production costs, making the farmers and customers dependent on imported foods and vegetables. Therefore, Nepalese agricultural products are unable to compete with products from neighboring countries. Addressing this challenge will require a combination of a number of measures including low-cost production support to farmers and policy reforms and regulations that promote local production.

- Valuing agriculture: this study found that agriculture is considered a low-value profession among the public. Therefore, it is important to educate people on the value of farming and its role in growing the rural economy. The government could include this information in school and university education.

- Mainstreaming the commercial pocket approach: since the commercial pocket approach has been found to be an effective way to commercialize smallholder agriculture, the GoN and other organizations working in the agriculture sector should consider mainstreaming the approach in their projects and programs.

- Considering household characteristics in agricultural development planning: to increase household income and impact livelihoods, the GoN and other agriculture development agencies should consider household socio-economic characteristics (see Table 1) when developing their policies and programs.

\section{Conclusions}

The major finding from this study is that there is potential to commercialize smallholder farming in the middle hills of Nepal. To realize this potential, the following general technical approaches and practices are recommended: adequate access to year-round irrigation, the use of improved production technologies and practices, improved access to rural markets, and improved production skills. Small commercial farmers also require business planning skills to make their production viable. These strategies would expand the participation of subsistence and risk-adverse producers in commercial agricultural production. A unique opportunity is the commercialization of high-value crops, especially for smallholder farmers. High-value crops, which offer higher income per unit of land, are particularly important in areas of water scarcity. In general, the findings and recommendations 
advanced in this study align with the Government of Nepal's agricultural development strategies (2015-2035). If implemented, the recommendations hold the potential to considerably improve the livelihoods of marginal farmers.

Author Contributions: Conceptualization, R.K.G., R.P.H.; methodology, R.K.G.; formal analysis, R.K.G.; investigation, R.K.G., R.P.H.; data curation, R.K.G.; writing-original draft preparation, R.K.G.; writing-review and editing, R.K.G., R.P.H., and visualization, R.K.G., R.P.H. All authors have read and agreed to the published version of the manuscript.

Funding: This research received no external funding. We are grateful to the Virginia Tech Open Access Subvention Fund for covering the article processing charges for this paper.

Acknowledgments: The authors would like to thank Bal Krishna Thapa, Khadka Sunar, Him Bahadur DC, and Gambar Singh Thapa who introduced the lead author to each community included in this research and provided logistical support during the field. We greatly appreciate the support of International Water Management Institute (IWMI Nepal) and International Development Enterprises (iDE Nepal), who provided vehicles and working space throughout the field research.

Conflicts of Interest: The authors declare no conflict of interest.

\section{References}

1. Cosic, D.; Dahal, S.; Kitzmuller, M. Climbing Higher: Toward a Middle-Income Nepal; World Bank: Washington, DC, USA, 2017.

2. GoN (Government of Nepal). Agriculture Development Strategy (ADS); Ministry of Agricultural Development, Government of Nepal: Kathmandu, Nepal, 2016.

3. CEIC. Nepal GDP per Capita. Global Database. Available online: https://www.ceicdata.com/en/indicator/ nepal/gdp-per-capita (accessed on 21 January 2020).

4. Adhikari, B. The State of economic development in Nepal. Int. J. Soc. Sci. Manag. 2018, 5, 43-45. [CrossRef]

5. Wester, P.; Mishra, A.; Mukherji, A.; Shrestha, A.B. The Hindu Kush Himalaya Assessment; Springer International Publishing: Cham, Switzerland; Basel, Switzerland, 2019.

6. GC, R.K.; Ranganathan, S.; Hall, R.P. Does rural water system design matter? A study of productive use of water in rural Nepal. Water 2019, 11, 1978. [CrossRef]

7. BRACED (Building Resilience and Adaptation to Climate Extremes and Disasters). Small Agro-Enterprise, Entrepreneurship and Market Development Manual; Anukulan-BRACED Project: Kathmandu, Nepal, 2019.

8. Kanini, B.R. Commercializing Agriculture. My Republica. Available online: https://myrepublica. nagariknetwork.com/news/commercializing-agriculture/ (accessed on 10 February 2020).

9. Samriddhi. Commercialization of Agriculture in Nepal; Discussion Paper. Kathamndu, Nepal. Available online: https://samriddhi.org/publications/commercialization-of-agriculture-in-nepal/ (accessed on 30 January 2020).

10. Jaleta, M.; Gebremedhin, B.; Hoekstra, D. Smallholder Commercialization: Processes, Determinants and Impact; ILRI: Nairobi, Kenya, 2009.

11. Pingali, P.L. From subsistence to commercial production systems: The transformation of Asian agriculture. Am. J. Agric. Econ. 1997, 79, 628-634. [CrossRef]

12. Von Braun, J.; Kennedy, E.T. Agricultural Commercialization, Economic Development, and Nutrition; Published for the International Food Policy Research Institute; Johns Hopkins University Press: Baltimore, MD, USA, 1994.

13. Gurung, N.K. Commercializing Agriculture. Quarterly Newsletter; JICA Nepal Office: Kathamndu, Nepal, 2012; Volume 64.

14. Thapa, G.; Kumar, A.; Joshi, P. Agricultural Transformation in Nepal; Springer: Berlin, Germany, 2019; ISBN 9813296488.

15. Aksha, S.K.; Juran, L.; Resler, L.M.; Zhang, Y. An analysis of social vulnerability to natural hazards in Nepal using a modified social vulnerability index. Int. J. Disaster Risk Sci. 2019, 10, 103-116. [CrossRef]

16. Acharya, K.K. Local governance restructuring in Nepal: From government to governmentality. Dhaulagiri J. Sociol. Anthropol. 2018, 12, 37-49. [CrossRef]

17. GC, R.K. Multiple use water systems and micro irrigation technologies for Koshi Basin-Lessons from Gandaki region, Nepal. In Proceedings of the Water-Livelihoods-Gender Nexus to Advance Koshi Basin Management, Kathmandu, Nepal, 24-25 March 2016; pp. 77-84. 
18. Baul, T.K.; Tiwari, K.R.; Ullah, K.A.; McDonald, M.A. Exploring agrobiodiversity on farm: A case from Middle-Hills of Nepal. Small-Scale For. 2013, 12, 611-629. [CrossRef]

19. Global South. Poverty in Nepal: Causes and consequences. Development Magazine. Available online: https://www.gsdmagazine.org/poverty-in-nepal-causes-consequences/ (accessed on 1 February 2020).

20. Creswell, J.W. Education Planning, Conducting, and Evaluating Quantitative and Qualitative Research; Pearson Education, Inc.: Boston, MA, USA, 2012.

21. Vogt, W.P.; Gardner, D.C.; Haeffele, L.M.; Vogt, E.R. Selecting the Right Analyses for Your Data: Quantitative, Qualitative, and Mixed Methods; Guilford Publications: New York, NY, USA, 2014.

22. FoodRisc Resource Centre (FRC). Mixed Methods Research. Available online: http://resourcecentre.foodrisc. org/mixed-methods-research_185.html (accessed on 10 February 2020).

23. Saldaña, J. The Coding Manual for Qualitative Researchers; Sage Publications Inc: London, UK, 2015.

24. Adhikari, J. Reviving Nepal's Rural Economy. The Kathmandu Post; Kantipur Publication: Kathmandu, Nepal. Available online: https://kathmandupost.com/columns/2019/08/19/reviving-nepals-rural-economy (accessed on 25 January 2020).

25. Pradhanang, U.B.; Pradhanang, S.M.; Sthapit, A.; Krakauer, N.Y.; Jha, A.; Lakhankar, T. National livestock policy of Nepal: Needs and opportunities. Agriculture 2015, 5, 103-131. [CrossRef]

26. Agrilinks. Agriculture in Nepal: How Do We Inspire a New Generation to go Into Farming? Available online: https:/www.agrilinks.org/blog/agriculture-nepal-how-do-we-inspire-new-generation-gofarming (accessed on 10 February 2020).

27. Jaquet, S.; Kohler, T.; Schwilch, G. Labour migration in the middle hills of Nepal: Consequences on land management strategies. Sustainability 2019, 11, 1349. [CrossRef]

28. Sunam, R.; Adhikari, J. How does transnational labour migration shape food security and food sovereignty? Evidence from Nepal. Anthropol. Forum 2016, 26, 248-261. [CrossRef]

29. IWMI (International Water Management Institute). Gender-Equitable Pathways to Achieving Sustainable Agricultural Intensification; CGIAR Research Program on Water, Land and Ecosystems (WLE); IWMI: Colombo, Sri Lanka, 2018.

30. GC, R.K. An Evaluation of Multiple Use Water Systems in Mid-Hills of Nepal: A Case Study of Phulbari Multiple Use Water Systems in iDE's Project Area of Shyangja District; MSc Internship Research Report; Wageningen University: Wageningen, The Netherlands, 2010.

31. Aryal, J.P.; Sapkota, T.B.; Khurana, R.; Khatri-Chhetri, A.; Jat, M. Climate change and agriculture in South Asia: Adaptation options in smallholder production systems. Environ. Dev. Sustain. 2019. [CrossRef]

32. GC, R.K.; Colavito, L. Benefits of multiple-use water systems (MUS) with micro irrigation for the smallholder farmers in the rural hills of Nepal. In Proceedings of the Sixth International Seminar on Small Scale Irrigation Systems: Challenges to Sustainable Livelihood, Kathmandu, Nepal, 15-16 February 2015; pp. 123-131.

33. Rijal, J.P.; Regmi, R.; Ghimire, R.; Puri, K.D.; Gyawaly, S.; Poudel, S. Farmers' knowledge on pesticide safety and pest management practices: A case study of vegetable growers in Chitwan, Nepal. Agriculture 2018, 8, 16. [CrossRef]

34. The New Humanitarian. Why Livestock Matters in Nepal? Available online: http://www. thenewhumanitarian.org/analysis/2013/07/24/why-livestock-matters-nepal (accessed on 5 February 2020).

35. Arain, A.; Arvidson, M.; Griffith, J.; Hutchison, C.; Lee, K. Agricultural Entrepreneurship: Opportunities for Nepali Youth; University of Wisconsin: Madision, WI, USA, 2018.

36. Colavito, L. The Commercial Pocket Approach for Smallholder Commercialization and Empowerment of Women and Disadvantaged Groups. AGRILINKS. Available online: https://www.agrilinks.org/blog/ commercial-pocket-approach-smallholder-commercialization-and-empowerment-women-and (accessed on 5 February 2020).

(C) 2020 by the authors. Licensee MDPI, Basel, Switzerland. This article is an open access article distributed under the terms and conditions of the Creative Commons Attribution (CC BY) license (http://creativecommons.org/licenses/by/4.0/). 